\title{
Rethinking the economics of capital mobility and capital controls
}

THOMAS I. PALLEY*

This paper reexamines the issue of international financial capital mobility, which is today's economic orthodoxy. Discussion is often framed in terms of the impossible trinity. That framing distorts discussion by representing capital mobility as having equal significance with sovereign monetary policy and control over exchange rates. It also distorts discussion by ignoring possibilities for coordinated monetary policy and exchange rates, and for managed capital flows. The case for capital mobility rests on neo-classical economic efficiency arguments and neo-liberal political arguments. The case against capital mobility is based on Keynesian macroeconomic inefficiency arguments, neo-Walrasian market failure arguments, and neo-Marxian arguments regarding distortion of the social structure of accumulation. Close examination shows the case for capital mobility to be extremely flimsy, pointing to the ideological dimension behind today's policy orthodoxy.

Keywords: capital mobility; capital controls; impossible trinity.

JEL Classification: F00; F32; F33.

\section{INTRODUCTION}

The 1990s saw global implementation of the Washington Consensus, a key element of which was financial liberalization that included promotion of international capital mobility. This paper re-examines the economics of international capital mobility and argues there are good economic reasons for restoring capital controls as a standard part of the policy arsenal.

The current moment constitutes an opportune time to re-engage this issue. The policy debate over capital controls has been closed for the past twenty-five

\footnotetext{
* Thomas Palley is an independent economist working in Washington DC. He can be reached at mail@ thomaspaley.com. Submitted: September 2008; Approved: December 2008.
} 
years. Now, it is gradually being pried open for both political and economic reasons ${ }^{1}$.

At the political level there is increasing popular disenchantment with globalization. At the economic level, proponents of financial liberalization were humbled by the unexpectedness and severity of the East Asian financial crisis of 1997. That crisis has compelled even die-hard liberalizers to qualify talk of capital flow liberalization in terms of a) prior development of appropriate financial market institutions, and b) sequencing of reforms that start with domestic financial markets and only extend gradually to international opening.

Additionally, even the International Monetary Fund (Kose et al., 2006) has been unable to find clear empirical support for the claim that capital mobility increases growth. Instead, where capital mobility is positively associated with growth, it is also associated with sound macroeconomic policies and benign macro conditions. Furthermore, countries that have grown fastest (China, the East Asian tigers, Chile, India) have all used controls. These findings have therefore created space for renewed debate about capital controls.

\section{REFRAMING THINKING ABOUT CAPITAL CONTROLS}

The contemporary view of capital controls is that if they are relevant, they are only relevant for developing countries. That view is prompted by the experience of the 1994 Mexican peso crisis and subsequent tequila effect that impacted Latin American; the 1997 East Asian financial crisis, the 1998 Russian ruble crisis; the 1999 Brazilian crisis; and the 2000 Brazilian and Argentine crises.

However, the issue of capital controls was previously viewed as extremely relevant for industrialized countries and was an important part of the European policy landscape in the twenty-five years after World War II. In 1982 capital mobility was at the center of the French franc crisis that prompted the Mitterrand government to abandon its Keynesian expansionary fiscal policies. Likewise, capital mobility was an issue in the Swedish krone and sterling crises of 1992. Most recently, capital mobility has been invoked to explain why long term U.S. interest rates did not increase during the period 2005-07 despite the Federal Reserve hiking short term rates. The claim is that this was due to China re-cycling its trade surplus back to the U.S. as capital inflows, but that implies capital mobility remains a legitimate concern for developed countries.

Analytical discussion of capital mobility is often framed in terms of Krug-

\footnotetext{
${ }^{1}$ Brazil is a country where there is support among many academic economists for capital controls and controls are viewed as a legitimate policy tool by sections of the political and policymaking community. This is illustrated by several recent articles on the issue of capital controls - see Carvalho and Siesu (2004), Oreiro et al. (2004), Oreiro (2004) and Ferrari Filho et al. (2005). The challenge is to extend this intellectual openness to other countries, the International Monetary Fund, the Bank for International settlement, the World Bank, and the multilateral regional development banks.
} 
man's (1999) construction of the "impossible trinity" that is shown in Figure 1. The argument is there exists a fundamental inconsistency between the trinity of fixed exchange rates, sovereign monetary policy that sets domestic interest rates, and unfettered international capital mobility.

Figure 1: The impossible Trinity

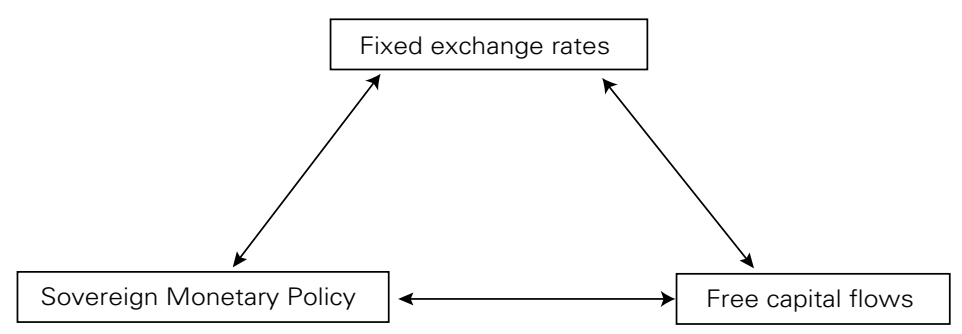

According to the impossible trinity a country can have any two of these three. If a country fixes its exchange rate and interest rate, it needs capital controls to block international arbitrage flows that would undermine the exchange and interest rate settings. If it fixes the exchange rate and has free capital flows, it loses control over the interest rate since monetary policy must be directed to maintaining the exchange rate. If it fixes the interest rate and has free capital flows, it loses control over the exchange rate which is determined by capital flows.

Whereas the economic logic of the impossible trinity is correct, the framework engages in intellectual sleight of hand. The exchange rate and interest rate are critical "macro" prices, and a country is unlikely to prosper if it gets these prices wrong. That means there is every reason why policymakers should want to control these variables. However, there is no equivalent reason for wanting free capital flows. Yet, the impossible trinity presents all three as if they are of equal standing, and in doing so distorts perceptions and debate.

\section{THE CASE FOR CAPITAL MOBILITY}

The impossible trinity begs the question of why a country would want unrestricted capital mobility. There are two sets of arguments for capital mobility as shown in Figure 2. One set is rooted in neo-classical microeconomic theory and concerns the efficient allocation of resources. The second set is rooted in neo-liberal political economy and concerns the need for constraints on government to promote good policy and freedom.

\section{Neo-classical economic efficiency arguments}

The neo-classical microeconomic efficiency arguments concern both stocks and flows. On the stock side, the argument is that capital mobility improves port- 
folio investment outcomes. It does this by increasing the range of investment opportunities, thereby increasing returns available to savers and increasing possibilities for diversification. That increases the efficiency of portfolios, which increases economic well-being - though this benefit goes largely to wealthy elites since wealth is highly concentrated.

Figure 2: The case for capital mobility

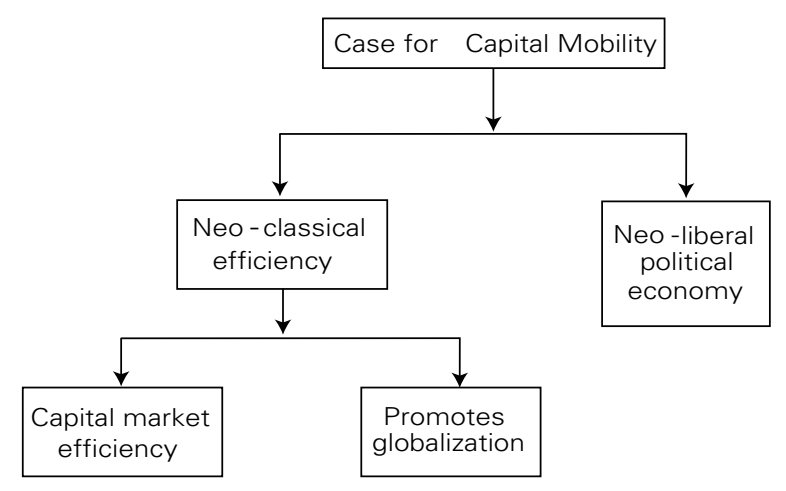

The second and most important efficiency claim regarding capital mobility is that it increases national saving and investment, thereby enhancing capital accumulation and economic growth. This is a flow argument based on the loanable funds theory of interest rates, according to which the interest rate is determined by demand and supply in the loanable funds market.

Analytically, the effects of capital mobility can be described by the following simple model that adds trade and exchange rate considerations to the conventional classical model ${ }^{2}$. Prior to capital market opening outcomes in the loanable funds market are determined by the following six equations:

$$
\begin{array}{ll}
y=y^{*} & \\
S=I & \\
S=S(i, y, e)+[T-G] & S_{i}>0, S_{y}>0, S_{e}>0 \\
I=I(i, y, e) & I_{i}<0, I_{y}>0, I_{e}<0 \\
X\left(e, y^{f}\right)=M(i, y, e) & X_{e}<0, X_{y f}>0, M_{e}>0, M_{i}<0, M_{y}>0 \\
e=p^{f} / p &
\end{array}
$$

Where $\mathrm{y}=$ output, $\mathrm{y}^{*}=$ full employment (natural) output, $\mathrm{S}=$ real domestic saving, $\mathrm{T}=$ lump sum taxes, $\mathrm{G}=$ government spending, $\mathrm{I}=$ real domestic investment, $\mathrm{X}$ = exports, $\mathrm{M}=$ imports, $\mathrm{i}=$ interest rate, $\mathrm{e}=$ exchange rate (foreign currency per unit of domestic currency), $\mathrm{p}^{\mathrm{f}}=$ foreign price level, and $\mathrm{p}=$ domestic price level.

\footnotetext{
${ }^{2}$ The full closed economy classical macro model without trade and exchange rates is described in Sargent (1979, Chapter 1).
} 
Equation (1) determines the level of output, which is equal to the full employment or natural level of output. Equation (2) is the loanable funds market clearing condition. Equation (3) determines national saving, which consists of private and public sector saving. Equation (4) is the domestic investment function. Equation (5) is the trade balance condition, and equation (6) determines the exchange rate $^{3}$.

The logic of the model is as follows. The level of output is equal to natural output, which is determined by the capital stock, labor supply, and the state of technology. The loanable funds market then determines the interest rate that equalizes saving and investment. Since there is no capital mobility, exports must equal imports. This is accomplished by price level adjustment that determines a real exchange rate consistent with trade balance.

After capital opening the loanable funds market is described by:

$$
\begin{aligned}
& y=y^{*} \\
& e=p^{f / p} \\
& i=i^{f} \\
& S=S\left(i^{f}, y, e\right)+[T-G]=S^{\prime} \\
& I=I\left(i^{f}, y, e\right)+X=I^{\prime} \\
& K M=I^{\prime}-S^{\prime}
\end{aligned}
$$

where $\mathrm{i}^{\mathrm{f}}=$ global interest rate, and $\mathrm{KM}=$ capital flow. If I' $>\mathrm{S}^{\prime}$ there is a capital inflow, and if I' $<$ ' ' there is a capital outflow. The logic is when I' $>S$ ' the economy is using more resources for investment and exports than it is saving, and this excess demand is provided via imports that are financed with capital inflows. The reverse holds for I' $<S$ ', in which case the country is running an export surplus and accumulating foreign capital.

The effect of capital mobility is to set the national interest rate equal to the global interest rate. Figure 3 shows the effect of capital opening on a developing economy. Such economies are viewed as being constrained by limited saving, but they have strong investment demand due to shortage of capital. The domestic interest rate $\left(i^{*}\right)$ is above the global interest rate $\left(i^{f}\right)$ because of strong investment demand owing to the country's relative scarcity of capital and saving. Capital mobility supposedly gives the economy access to the global saving pool with its lower interest rate. The result is capital inflows that increase investment, lower domestic saving, and increase domestic consumption. This makes the country better off as capital opening accelerates capital accumulation while smoothing inter-temporal consumption, enabling more consumption today that is repaid with the returns from increased investment.

Figure 4 shows the case of a developed economy that opens itself to capital

\footnotetext{
${ }^{3}$ Throughout the paper the exchange rate (e) is denoted as foreign currency per unit of home currency. That means a higher value of e corresponds to exchange rate appreciation, and a lower value corresponds to depreciation.
} 
Figure 3: The effect of capital mobility on a developing country

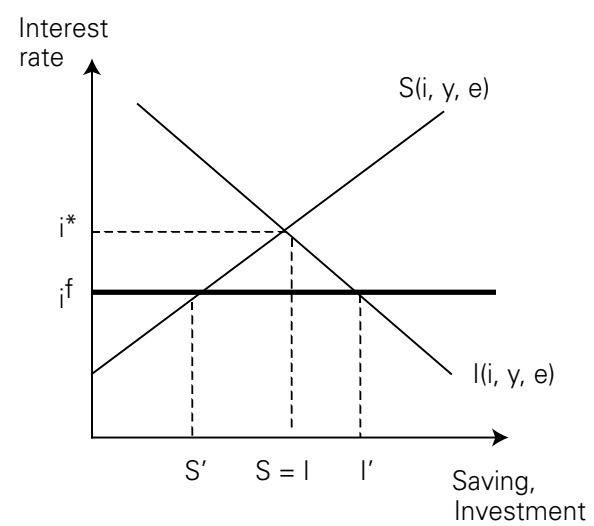

Figure 4: The effect of capital mobility on a developing country

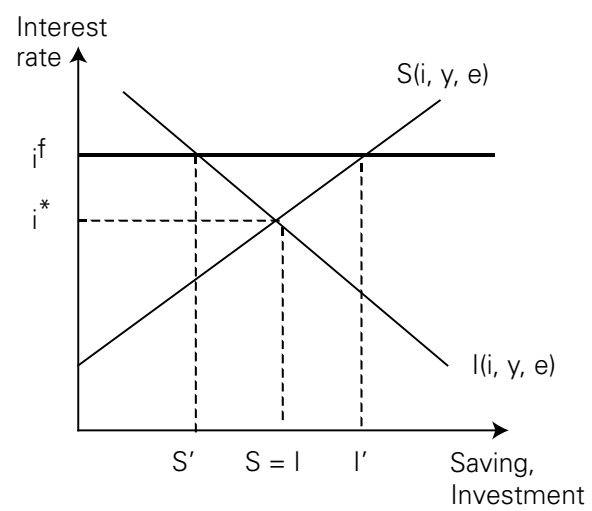

mobility. This case is the symmetric opposite of a developing country. Now the global interest rate $\left(\mathrm{i}^{\mathrm{f}}\right)$ is above the domestic interest rate $\left(\mathrm{i}^{*}\right)$ because the country is relatively capital abundant compared to the rest of the world. Consequently, there is a net capital outflow. Domestic investment falls but domestic saving rises. The logic is that the higher interest rate encourages more saving but discourages domestic investment. Instead, investment is directed offshore to developing countries where the marginal efficiency of investment is higher. The country is made better off because it can access higher returns by investing offshore. Interestingly, consumption falls due to increased saving, but consumption is higher in future periods due to increased income from higher returns on foreign investment.

The third and final neo-classical efficiency argument for capital mobility is an informal claim that it yields a host of collateral benefits. This seems to be an increasingly popular assertion in business media. The claim is that capital mobility fosters trade, FDI, technology transfer, global production chains, and financial de- 
velopment, and together this improves efficiency and growth. From a conventional neo-classical perspective these developments increase global productive efficiency through application of the principle of comparative advantage, thereby benefitting all countries.

However, this "collateral benefits" argument is challenged by lack of empirical support regarding a robust positive association between financial liberalization and growth (Kose et al., 2006). Furthermore, the microeconomic basis of the collateral benefits argument is challenged by Gomory and Baumol (2000) and Palley (2008a), who argue that FDI and outsourcing can be good for companies but may be bad for national income and wages. Lastly, the argument ignores the fact that trade, financial development, FDI, and technology transfer also take place with capital controls, as evidenced by China.

\section{The neo-liberal political economy case for capital mobility}

The neo-classical economic efficiency argument for capital mobility is complemented by neo-liberal political economy arguments. One argument that has its origins in Tiebout's (1956) theory of local public goods is that capital mobility creates a competitive market discipline that improves the quality of governance and policy. The claim is capital will tend to exit countries with bad governance and flow toward countries with good governance. That in turn creates a "race to the top" between country governments as they compete to attract productive capital, resulting in better governance and more efficient markets that are free of government distortions ${ }^{4}$.

A second Hayekian-styled (Hayek, 1944) argument for capital mobility is that the freedom to move capital and property is an intrinsic element of personal freedom. Freedom of movement is an essential element of choice, and choice is the essence of freedom. That makes capital mobility both a means and an end. Capital mobility helps protect personal freedom by disciplining governments, and it is also an essential part of personal freedom. However, there is widespread recognition of the legitimacy of restrictions on people moving between national jurisdictions, so it is unclear why capital should be treated differently.

A third argument is that controls generate costly rent seeking (Krueger, 1974). Thus, even if there is a market failure that appears to warrant capital controls, such a policy solution may generate worse outcomes than doing nothing. This is because 1) agents will expend valuable resources engaging in rent seeking activity that aims to circumvent controls by influencing government, and 2) such rent-

\footnotetext{
${ }^{4}$ This type of argument can be thought of as a dynamic version of Tiebout's (1956) theory of local public expenditure whereby agents self-select and choose to live in jurisdictions supplying their desired level of public goods. Capital mobility creates competition among jurisdictions to attract productive citizens, leading to improvements in governance that increase economic efficiency and make all better off. Race to the bottom logic works in the opposite direction with jurisdictions cutting standards to gain a competitive cost advantage.
} 
seeking activity may corrupt government and contribute to bad policy and governance.

A fourth pragmatic argument against capital controls is that they have limited effectiveness in the presence of sophisticated financial markets. Carvalho and Garcia (2006) report on the Brazilian experience with capital controls in the 1990s and report that they were only temporarily effective deterring inflows, for a brief period of two to six months. They then hypothesize that this is because financial institutions performed sophisticated operations to avoid controls.

Balanced against this, several empirical studies find capital controls have statistically significant effects that go in the theoretically predicted direction. Gregorio et al. (2000) find that unremunerated reserve requirements on inflows tilt the composition of inflows toward longer maturity as predicted by theory (Palley, 2005). Edwards (2005) reports that countries with capital controls have smaller growth declines once a financial crisis begins. Lastly, Edwards and Rigobon (2005) report tightening of capital controls on inflows depreciates the exchange rate and capital controls also reduce the vulnerability of the nominal exchange rate to external shocks.

These findings of statistically significant effects from capital controls mean controls work even if there is avoidance and evasion. Moreover, the effect of controls would be strengthened by greater political commitment to capital controls, tougher enforcement of controls with larger penalties, and greater international cooperation regarding enforcement that would follow universal acceptance of capital controls as a legitimate policy tool.

\section{THE CASE AGAINST CAPITAL MOBILITY}

Balanced against the above neo-classical and neo-liberal arguments for capital mobility are three different types of arguments against capital mobility. These counter arguments are illustrated in Figure 5 and can be labeled (1) the Keynesian macroeconomic efficiency argument, (2) the neo-Walrasian market failure argument, and (3) the neo-Marxian social structure of accumulation argument.

Figure 5 is important as it highlights the different theoretical perspectives in play. Today's intellectual climate is dominated by neo-classical economics. This climate allows neo-Walrasian market failure arguments to get a hearing but Keynesian and Marxian social structure of accumulation arguments are excluded. This exclusion prevents full presentation of the case against capital mobility and it highlights the policy significance of macroeconomic theory. Put bluntly, theory matters for policy justification, and if theories are politically excluded that will distort the policy debate and policy choice. That is why intellectual openness and economic theory should be of concern to pragmatic politicians. 
Figure 5: The case against capital Mobility

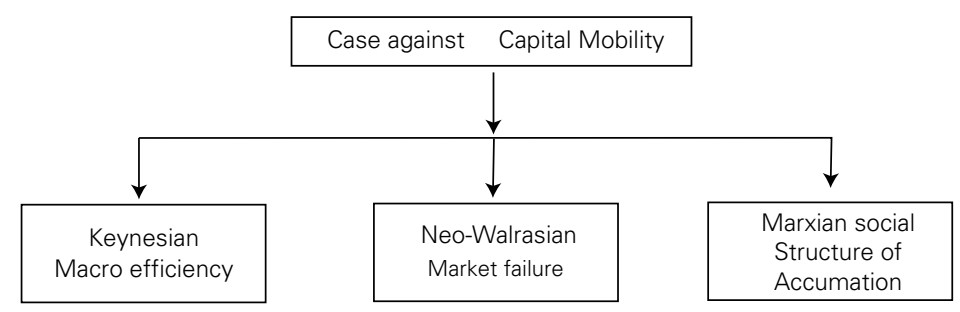

\section{The Keynesian macroeconomic case against capital mobility}

The Keynesian challenge to capital mobility rests on a fundamentally different theoretical construction of the determination of exchange rates, interest rates, saving, and investment. First, whereas the neo-classical model has the exchange rate determined by purchasing power parity (PPP), the Keynesian model treats the exchange rate as a financial price that is determined in the foreign exchange (FX) market. Second, interest rates are not determined in a fictional loanable funds market, but are instead determined in financial markets that can be significantly affected by the policies and actions of central banks. Third, saving and investment are determined in the goods market by the consumption and investment spending decisions of households and firms, and are equalized by output adjustment rather than interest rate adjustment.

Figure 6 shows the determination of saving, investment, and net exports in the Keynesian model. Output adjusts in response to excess (or deficient) aggregate demand $(\mathrm{AD})$, and this adjustment process continues until output and $\mathrm{AD}$ are equalized. At that point leakages out of the flow of circular income (saving) equal injections into the circular flow (investment, government budget deficit, and net exports).

Figure 6: Determination of saving, investment,

\& net exports in the Keynesian model

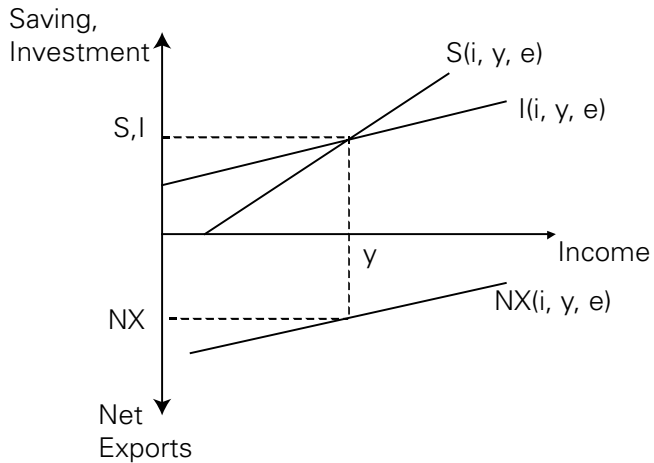


This Keynesian process of equilibrium output determination is described by the following equations:

$$
\begin{aligned}
& y=A D \\
& y=C(i, y, e)+S(i, y, e)+T \quad C_{i}<0, C_{y}>0, C_{e}>0, S_{i}>0, S_{y}>0, S_{e}>0 \\
& A D=C(i, y, e)+I(i, y, e)+G+N X(i, y, e) \\
& I_{i}<0, I_{y}>0, I_{e}<0, N_{i}>0, N X_{y}<0, N X_{e}<0
\end{aligned}
$$

Where $\mathrm{y}=$ income (output), $\mathrm{AD}=$ aggregate demand, $\mathrm{C}=$ consumption, $\mathrm{S}=$ saving, $\mathrm{T}=$ lump-sum tax payments, $\mathrm{I}=$ investment spending, $\mathrm{G}=$ government spending, and $\mathrm{NX}=$ net exports (exports minus imports). Combining equations (10) - (12) and re-arranging, then yields

(13) $S(i, y, e)=I(i, y, e)+[G-T]+N X(i, y, e)$

Goods market equilibrium requires that demand leakages ( $\mathrm{S}$ ) equal demand injections $(\mathrm{I}+[\mathrm{G}-\mathrm{T}]+\mathrm{NX})$. Given the equilibrium level of income determined in goods markets, there is an associated level of net exports.

The exchange rate, which affects leakages and injections into the circular flow of income, is determined in the foreign exchange market by the inter-play of demand and supply for different currencies. The demand for home country currency is principally determined by foreigners who need currency to pay for their purchases of the home country's exports and by foreigner desires to purchase assets in the home country. The supply of home country currency is principally determined by home country residents who sell their currency to buy foreign currency to pay for imports and to purchase foreign country assets.

Figure 7 shows the determination of the exchange rates in the Keynesian model with floating exchange rates. Figure 8 shows the determination of exchange rates in the Keynesian model with fixed rates. In the latter case any discrepancy between demand and supply at the fixed exchange rate is covered by central bank intervention, and that intervention shows up as the official settlement balance (OSB).

Figure 7: Determination of exchanges rates in the Keynesian model with float rates

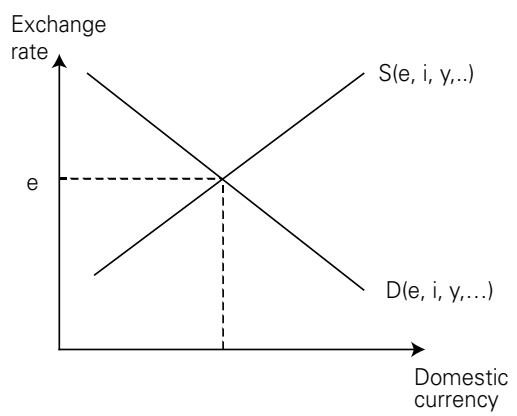

Figure 8: Determination of exchanges rates in the Keynesian model with fixed rates

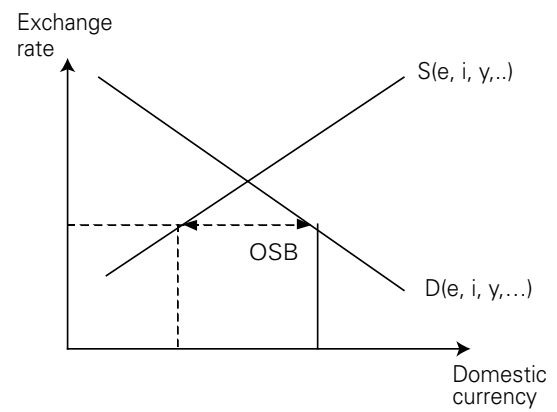

Revista de Economia Política 29 (3), 2009 
The Keynesian case against capital mobility rests on the argument that it can cause macroeconomic problems, including unemployment and inflation. In a regime of fixed exchange rates capital inflows compel official intervention to prevent appreciation, which can give rise to undesirable monetary expansion that can cause generalized and asset price inflation. Conversely, capital outflows compel intervention to protect the exchange rate, and that runs the risk of running out of reserves and tempting speculative attacks on the exchange rate.

For Keynes (1942), a deeper problem was that a country might need low interest rates for full employment, yet capital outflows might compel the monetary authority to push the domestic interest rate above that consistent with full employment to protect the exchange rate. This "Keynes Problem" is illustrated in Figure 9. The right hand panel shows the interest rate $\left(\mathrm{i}^{\mathrm{y}}\right)$ needed to secure full employment output $\left(\mathrm{y}^{\mathrm{T}}\right)$ in the goods market, while the left hand panel shows the interest rate $\left(\mathrm{i}^{\mathrm{e}}\right)$ needed to maintain the fixed exchange rate $\left(\mathrm{e}^{\mathrm{T}}\right)$ given full employment output and foreign interest rates $\left(\mathrm{i}_{\mathrm{f}}^{\mathrm{f}}\right)$. Conventional classical macroeconomics dismisses this Keynes problem on the grounds that price deflation will ensure full employment. However, it is now clear that price deflation can be destabilizing and can actually aggravate the problem of inadequate $\mathrm{AD}$ and unemployment (Tobin, 1975, 1980; Palley, 2008b, 2008c).

Figure 9: The Keynes Problem

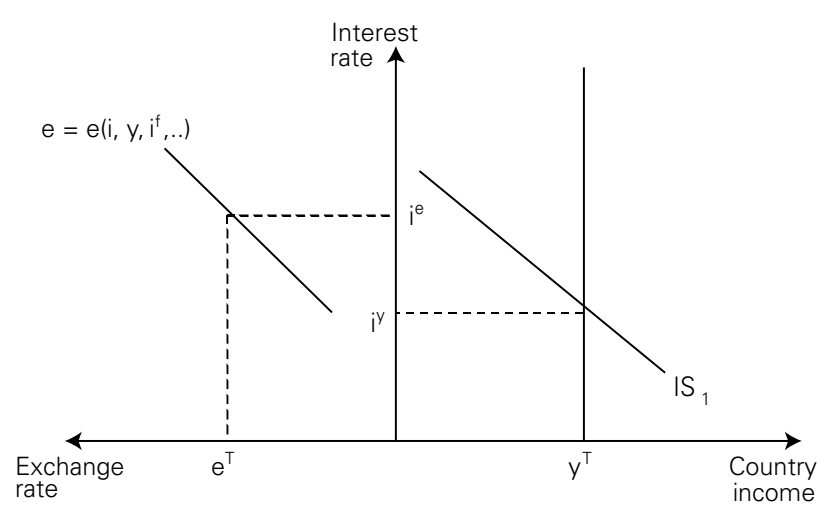

With flexible exchange rates, capital openness can lead to large inflows that appreciate the exchange rate, causing a contraction of investment spending and net exports. That in turn reduces output and employment, as shown in Figure $10^{5}$. This problem is amplified in a globalized world in which capital flows are larger and in which economies more sensitive to exchange rates owing to an increase in the share of exports and imports in GDP.

\footnotetext{
${ }^{5}$ Figure 10 shows aggregate saving as increasing in response to an exchange rate appreciation $\left(S_{e}>0\right)$. However, in principle aggregate saving could fall as the sign of $S_{e}$ is theoretically ambiguous.
} 
Figure 10: Effect of capital inflows in the Keynesian model with flexible exchange rates $\left(e_{0}<e_{1}\right)$

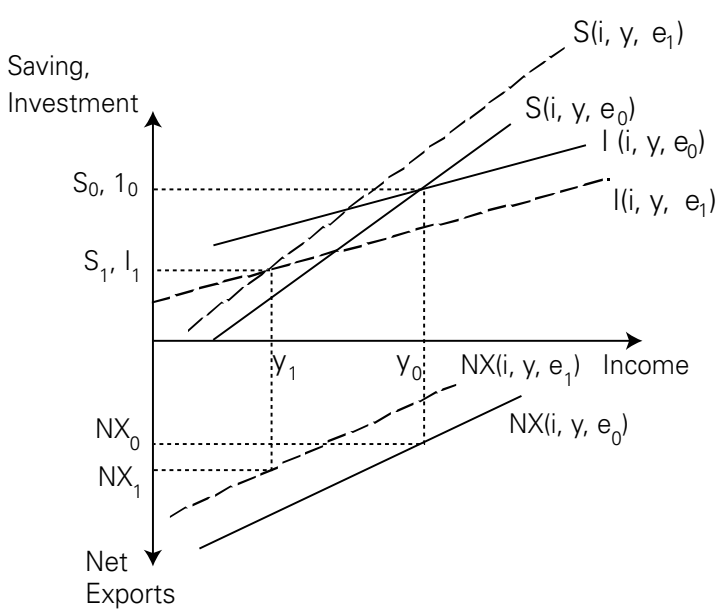

Moreover, there can be additional problems when one country opens its capital markets while others do not. In this event, the country with capital controls can pursue strategic "beggar my neighbor" policies that frustrate market exchange rate adjustment mechanisms, making it better off at the expense of open country. A recent example of this is China, which fixed its exchange rate vis-à-vis the U.S. dollar at an undervalued rate, and capital controls enabled it to maintain that rate despite an enormous trade surplus.

A last problem with open capital markets concerns the impact of capital inflows on internal balance. For example, during the recent (2001-2007) U.S. economic expansion capital inflows hampered long-term interest rates from rising and frustrated the Federal Reserve's attempt to raise the general level of interest rates. This contributed to an unbalanced expansion marked by a boom in the nontraded (NT) goods sector (housing) and a slump in the traded (T) goods sector (manufacturing).

This internal balance problem is illustrated in Figure 11. The top right hand panel shows non-traded sector employment as a negative function of the interest rate. The bottom left hand panel show traded sector employment as a positive function of the exchange rate defined as domestic currency per unit of foreign currency. The top left hand panel then relates the exchange rate to the domestic interest rate. The problem results when a surge in capital inflows $\left(\mathrm{X}_{0}<\mathrm{X}_{1}\right)$ shifts the exchange rate function left, causing an appreciation of the exchange rate and a decline in the interest rate. This spurs a boom in the NT sector and a slump in the T sector.

Moreover, this shift can be cumulative so that an appreciating exchange rate and rising asset prices caused by falling interest rates causes further capital inflows 
Figure 11: The Greenspan Problem $\left(\mathrm{X}_{0}<\mathrm{X}_{1}\right)$

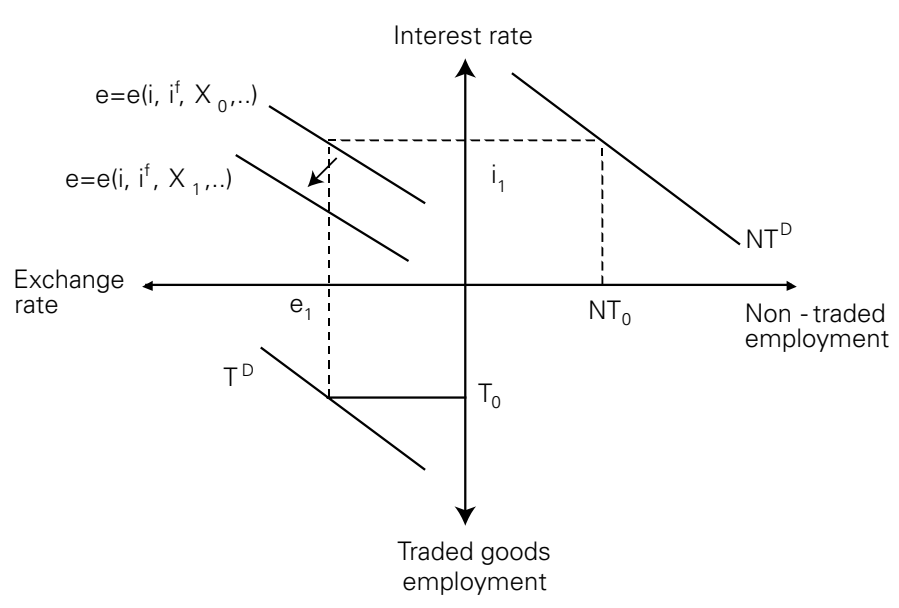

that further shift the exchange rate function ${ }^{6}$. Policymakers aiming for balance in the NT and T goods sector would like to target the interest rate on the NT sector and the exchange rate on the $\mathrm{T}$ goods sector. Capital mobility frustrates this.

To summarize, whereas the classical macroeconomic model predicts unambiguously good outcomes from capital mobility, the Keynesian model is less sanguine. In the classical model capital mobility impacts economic outcomes via the loanable funds market, improving the global allocation of saving. In effect, the classical model is a corn model in which corn stocks (saving) get reallocated (invested) to countries where corn grows faster, thereby producing more corn for all. Moreover, there can be no employment impacts as the economy is assumed to be at full employment.

The Keynesian model views the loanable funds market as a fiction. Instead, capital flows affect the foreign exchange market, giving rise to exchange rate effects that can have significant adverse consequences on employment and output.

That raises the question when is capital mobility a good thing in the Keynesian model? The short answer is when a country suffers from a shortage of foreign money (i.e., there is a foreign exchange supply gap). For instance, a developing country may want to import capital goods but is running a trade deficit and will not benefit from exchange rate depreciation owing to adverse terms of trade effects and higher imported inflation. In this case the country may be better off by borrowing abroad.

\footnotetext{
${ }^{6}$ This pattern has similarities with the East Asian financial crisis of 1997. In East Asia, capital inflows drove pro-cyclical destabilizing movements in financial markets. Thus, inflows drove interest rates down and increased asset prices, giving rise to strong financial accelerator effects that amplified the boom in the NT sector. Meanwhile, appreciating exchange rates undermined the T goods sector, contributing to a deteriorating trade outlook.
} 
The important feature is the underlying problem capital mobility addresses is not a shortage of domestic saving as claimed by loanable funds theory, but rather a shortage of foreign exchange to purchase foreign produced goods. The Washington Consensus talks of international capital mobility as analogous to domestic capital mobility, thereby framing international financial opening as analogous to domestic financial deregulation. From a Keynesian perspective that analogy is wrong and international financial capital mobility is about filling foreign exchange gaps rather than improving financial intermediation and the allocation of capital.

\section{The neo-Walrasian case against capital mobility}

A Keynesian perspective emphasizes macroeconomic problems arising from capital mobility. A neo-Walrasian perspective emphasizes microeconomic market failure problems that result in allocative inefficiencies, the solution to which are capital controls.

One source of micro inefficiency is noise traders (De Long et al., 1990) who generate excessive exchange rate volatility and exchange rate mispricing. That volatility and mispricing distorts trade and foreign investment decisions, giving rise to microeconomic inefficiencies ${ }^{7}$.

Capital mobility can also amplify endemic proclivities to runs and financial panics by encouraging speculative short term "hot money" flows. When these flows reverse, that can trigger financial disruption that causes real economic damage. This type of problem is likely to be particularly acute in developing economies. First, they tend to experience inflows that are large relative to the system. Second, they tend to have weaker regulatory and institutional frameworks that make them more vulnerable to financial market disruptions. Third, exchange rate depreciations resulting from sudden reversals are especially destabilizing in developing countries as they tend to be international debtors with foreign currency denominated debt, making them prone to exchange rate induced debt crises.

The problem of exchange rate instability is illustrated in Figure 12, which shows how the foreign exchange market can have multiple equilibria. Capital flows can cause significant local volatility around each equilibrium and can also cause large jumps between equilibriums.

The problem of hot money flows is discussed in Palley (2005) who presents a model in which there are two types of investors - short-term speculators and longterm patient investors. In such a situation Chilean-style temporary reserve requirements on capital inflows can act as a screening mechanism that discourages inflows from short-term speculators. That is because the cost of temporary reserve

\footnotetext{
${ }^{7}$ The issue of microeconomic inefficiency in the foreign exchange market due to speculation is examined in Palley (2001a) as part of a discussion of the Tobin tax.
} 
Figure 12: The Problem of exchange Rate Instability

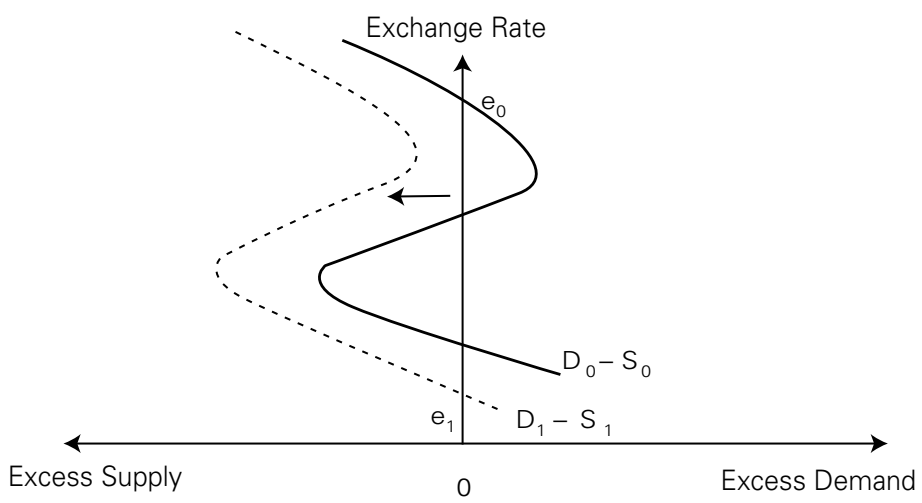

requirements is small for patient investors who plan to stay a long while, but it is very high for speculators who plan on a quick roundtrip in and out of a currency.

A similar logic holds for the Tobin tax (Palley, 1999) where a small exchange transactions tax is of little consequence to importers and exporters but it is highly significant to noise traders speculating on minute fractional movements of exchange rates. Consequently, a Tobin tax also has the properties of a screening mechanism.

The neo-Walrasian critique rests on imperfections in capital markets - be they due to the existence of speculators who create noise and impose negative externalities on others or due to imperfect or asymmetric information among market participants. This market imperfections approach is consistent with both Classical and Keynesian macroeconomics, and neo-Walrasian considerations can be included in either type of model.

However, the impact is larger when neo-Walrasian concerns are introduced into classical macro models. This is because they move the classical model's equilibrium away from the first best, enabling the classical model to generate the type of sub-optimal outcomes Keynesians are concerned with. Contrastingly, adding neo-Walrasian concerns to the Keynesian model merely adds another reason (albeit with a different economic logic) why the economy will be away from the first best position and why policy intervention is needed.

\section{The neo-Marxian social structure of accumulation case against capital mobility}

Capital mobility gives financial capital the right of international exit. The neoMarxian social structures of accumulation (SSA) approach emphasizes how that right confers on capital the power to discipline governments, affect policy, and transform the structure of economy (Crotty and Epstein, 1996). This power affects both developed and developing economies.

The classic example of this power in action is the French franc crisis of 1982- 
83. That crisis compelled the Socialist Party government of President Mitterand in France to do a policy U-turn and abandon its Keynesian policies aimed at reflating the French economy. In hindsight, that U-turn signaled a permanent movement away from explicitly Keynesian policies in Europe. Thereafter, European policymakers shifted their attention to creating a common European currency, a project that has imposed a permanent deflationary policy bias because of its emphasis on fiscal austerity and very low inflation in order to build so-called "monetary credibility" for the new European currency.

The debate about the constraining effect of capital mobility on "policy space" (Bradford, 2005; Grabel, 2000; Palley, 2001b) partially captures some of the issues raised by the SSA critique. Thus, different international arrangements and rules affect the space available for countries to pursue economic policies of their choosing. This is because institutional arrangements and rules affect the costs and benefits of alternative policies.

The pressures that capital mobility places on policy space and choice can again be understood through the Tiebout (1956) local public goods model. Whereas neo-liberals view capital mobility as promoting a dynamic competition between governments that produces a race to the top in governance and policy, SSA theory sees it as creating a race to the bottom. According to SSA logic, firms use the threat of exit to erode standards that are socially desirable. Moreover, that can result in a prisoner's dilemma situation in which unrestricted competition between firms produces an "uncooperative" equilibrium that leaves firms worse off. This is exemplified by competition over labor standards (Palley, 2004). From this perspective, capital controls can be viewed as a device for preventing undesirable competition and ensuring the superior "cooperative" equilibrium.

However, the SSA critique runs deeper than the policy space debate. Thus, the power given to capital by capital mobility not only affects surface policies, it may also dull the aspiration to and feasibility of social democracy. This impact seems to be particularly evident in Brazil, where it can be argued that globalization has tamed the left (Palley, 2006). Thus, in Brazil under President Lula, poverty alleviation programs appear to have replaced an earlier vision of social democracy that would tackle deep lasting social and economic inequalities.

\section{ABANDONING THE IMPOSSIBLE TRINITY}

The impossible trinity focuses on the inconsistency between sovereign monetary policy, fixed exchange rates, and free capital flows. That framing has promoted today's policy configuration that consists of sovereign monetary policy, free capital flows, and floating exchange rates.

The problem with the impossible trinity is that it misrepresents the policy choice, making it look as if the current configuration is an optimal policy combination when it is not. In this regard, there are two types of misrepresentation. The first is to make it look as if sovereign monetary policy, control over the exchange 
rate, and free capital flows are of equal policy importance, when they are not. The second is that the impossible trinity presents an incomplete policy menu that leaves much off the table. This omission includes a) coordinated monetary policy across countries; b) managed exchange rates between countries; and c) managed capital flows.

The impossible trinity emerged out of the work of Milton Friedman (1953) and Robert Mundell (1961a, b). That work is infused with the laissez-faire predispositions of those authors, and as such the impossible trinity frame traps policy debate by obscuring other possibilities. That suggests it is time to time to abandon the impossible trinity frame.

Figure 13 shows the evolution of international financial policy over the decades, shifting from a gold standard regime of fixed exchange rates with capital mobility to the current regime of flexible exchange rates with capital mobility. The decade of the 1970s was pivotal. The pressures of that decade were used to ram through a program of deregulation and laissez-faire in all spheres of policy, including international economic policy. As a result, policymakers too easily surrendered the benefits of capital controls.

Figure 13: The evolution of policy regimes

\begin{tabular}{|c|c|c|c|}
\hline & & \multicolumn{2}{|c|}{ Exchange Rates } \\
\hline & & Fixed & Flexible \\
\hline \multirow{2}{*}{$\begin{array}{l}\text { Capital } \\
\text { Controls }\end{array}$} & Yes & $1950-60 s$ & $1970 s$ \\
\hline & No & $\begin{array}{c}\text { Gold standard } \\
\text { 1920-30's }\end{array}$ & $1980-2000 s$ \\
\hline
\end{tabular}

At this stage there is need to create a new policy agenda of managed exchange rates and managed capital flows. That agenda can be thought of as aiming to capture the advantages of both fixed and flexible exchange rates and both free and controlled capital flows. The impossible trinity should be replaced by a possible trinity of coordinated monetary policy, managed exchange rates, and managed capital flows.

This possible trinity is shown in Figure 14, and its elements are mutually supportive rather than antagonistic. Of course, the possible trinity raises difficult issues of international political economy regarding what does a regime of co-operative monetary policy and managed exchange rates look like and how is it achieved.

Countries can significantly go it alone on capital controls, though the effectiveness of controls depends on the degree of international cooperation regarding enforcement. However, co-operative monetary policy and managed exchange rates are intrinsically joint efforts. Co-operative monetary policy requires countries col- 
Figure 14: The Possible Trinity

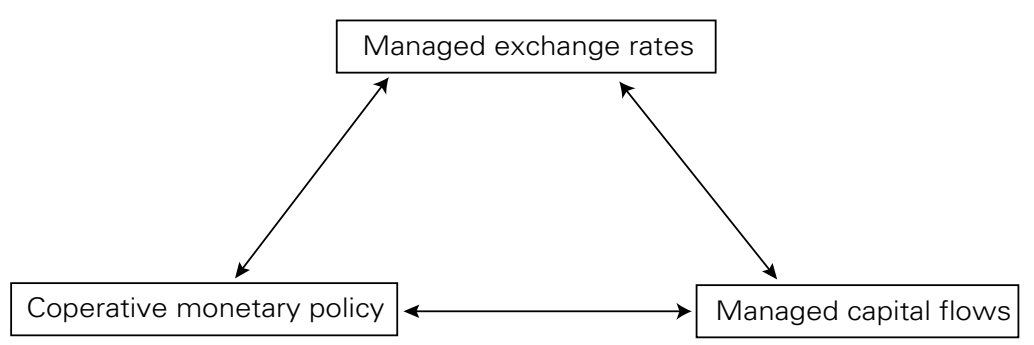

laborate on issues of interest rate setting and inflation management. Likewise, managed exchange rates require countries to agree on rules for managing the exchange rate. Those rules involve criteria for establishing the target exchange rate, as well as rules governing the process of exchange rate intervention. Palley (2003, pp. 77-79) discusses these rules of exchange rate management, placing particular emphasis on the need for the country whose currency is appreciating to conduct exchange rate interventions. That assignment prevents the possibility of the intervening central bank running out of foreign currency reserves and being beaten by a concerted attack by speculators ${ }^{8}$.

\section{CONCLUSION: THE POLITICS AND SOCIOLOGY OF POLICY ADVICE}

Capital mobility has become today's economic orthodoxy, yet the pure economic case for capital mobility is amazingly flimsy. Instead, there are strong grounds for believing capital controls can contribute significantly to economic stability and create important space for autonomous national economic policy. That capital mobility dominates the policy agenda so completely is indicative of the ideological dimension of the debate.

Whether controls are well or poorly used depends on the quality of governance. Neo-liberals tend to automatically assume they will be used badly and make that assumption a centerpiece of opposition against capital controls. However, a combination of democratic transparent accountable government, a professionalized civil service, and strong civil society can ensure that capital controls are used well. The neo-liberal concern with regulatory capture is real, but the answer should be promotion of effective governance rather than abandonment of this important policy tool.

Finally, sociology matters. Official policy discussion regarding capital controls and exchange rate regimes has been led by institutions such as the International

\footnotetext{
${ }^{8}$ Cooperative monetary policy is essential to cooperative managed exchange rate policy. Countries will not agree to defend the exchange rate of another country if they believe the weaker country is engaged in monetary mismanagement.
} 
Monetary fund (IMF), the World Bank, the Organization for Economic Cooperation and Development (OECD), and the Bank for International Settlements (BIS). These organizations are peopled by high-paid international bureaucrats drawn from around the world, who own global investment portfolios, and have homes and family in more than one country. A strictly neo-classical standpoint suggests these bureaucrats have a strong private interest in capital mobility, which likely taints the advice these institutions provide. That potential sociological contamination provides additional grounds for fresh public debate over capital controls.

\section{REFERENCES}

BRADFORD, C., Jr., "Prioritizing Economic Growth: Enhancing macroeconomic Policy Choice," G-24 Discussion paper No. 37, April 2005.

CARVALHO, B. and M. GARCIA, "Ineffective Controls on Capital Flows Under Sophisticated Financial Markets: Brazil in the Nineties,” NBER Working Paper No. 12283, NBER, June 2006.

CARVALHO, F. C. and SICSÚ, J. (2004). "Controvérsias recentes sobre controles de capitais". Brazilian Journal of Political Economy, Vol. 24, N.2 (April-June).

CROTTY, J. and G. EPSTEIN, “In Defence of Capital Controls”, Socialist Register (1996), reprinted in L. Panitch, C. Leys, A. Zuege and M Konigs (eds), The Globalization Decade: A Critical Reader, London: The Merlin Press, 80-110, 2004.

DE LONG, J.B., SHLEIFER, A., SUMMERS, L.H., and WALDMAN, R.J., "Noise Trader Risk in Financial Markets," Journal of Political Economy, 98 (1990), 703-38.

EDWARDS, S., "Capital Controls, Sudden Stops and Current Account Reserves," NBER Working Paper N. 11170, NBER, March 2005.

EDWARDS, S. and R. RIGOBON, "Capital Controls, Exchange Rate Volatility and External Vulnerability,” NBER Working Paper N. 11434, NBER, June 2005.

FERRARI FILHO, F.; JAYME JR, F.; LIMA, G.T; OREIRO, J.L; PAULA, L.F. (2005). "Uma avaliação crítica da proposta de conversibilidade plena do Real". Brazilian Journal of Political Economy, Vol. 25, N.1 (January-March).

FRIEDMAN, M., "The Case for Flexible Exchange Rates," in Essays in Positive Economics, Chicago: Chicago University Press, 1953.

GOMORY, R.E. and W.J. BAUMOL, Global Trade and Conflicting National Interest, Cambridge: MIT Press, 2000.

GRABEL, I., "The Political Economy of "Policy Credibility": the New-Classical Macroeconomics and the remaking of Emerging Economies," Cambridge Journal of Economics, 24 (2000), 1-19.

GREGORIO, J., S. EDWARDS, and R. VaLdes, “Controls on Capital Flows: Do They Work?” NBER Working Paper No. 7645, NBER, April 2000.

HAYEK, F., The Road to Serfdom, Chicago: University of Chicago Press, 1944.

KEYNES, J.M., Letter to R.F. Harrod, 19 April 1942.

KOSE, M.A., E. PraSad, K. ROGOFF, and S. WEI, "Financial Globalization: A Reappraisal," IMF Working Paper WP/06/189, August 2006.

KRUEGER, A.O., “The Political Economy of Rent-Seeking Society,” American Economic Review, 64 (June 1974), 291-303.

KRUGMAN, P., “O Canada: A Neglected Nation Gets Its Nobel,” Slate Magazine, posted October 19, 1999.

MUNDELL, R.A., "Capital Mobility and Stabilization Policy under Fixed and Flexible Exchange Rates," Canadian Journal of Economics and Political Science, 29 (November 1961a), 475 - 485. , "Flexible Exchange Rates and Employment Policy," Canadian Journal of Economics and Political Science, 27 (November 1961b), 509-17. 
OREIRO, J.L (2004). “Autonomia de política econômica, fragilidade externa e equilíbrio do balanço de pagamentos: a teoria econômica dos controles de capitais”. Economia \& Sociedade, Vol. 13, N.2 (July-December).

OREIRO, J.L; PAULA, L.F; SILVA, G.J. (2004). "Por uma moeda parcialmente conversível: uma crítica a Arida e Bacha”. Brazilian Journal of Political Economy, Vol. 24, N.2 (April-June).

PALLEY, T.I., "The Economics of Outsourcing: How Should Policy Respond?” Review of Social Economy, 66:3 (2008a), 279-95.

, "The Macroeconomics of Aggregate Demand and the Price Level," Investigacion Economica, LXVII (263), January-March 2008b, 49-66.

"Keynesian Models of Deflation and Depression Revisited," Journal of Economic Behavior and Organization, 68 (October 2008c), 167 - 77.

, "Globalization Tames the Left in Brazil," YaleGlobal, September 5, 2006.

"Chilean Unremunerated Reserve Requirement Capital Controls as a Screening Mechanism," Investigacion Economica, LXIV (January/March 2005), 33-52.

"The Economic Case for International Labor Standards," Cambridge_Journal of Economics, 28 (January 2004), 21-36.

"The Economics of Exchange Rates and the Dollarization Debate: The Case Against Extremes," International Journal of Political Economy, 33 (Spring 2003), 61-82.

"Destabilizing Speculation and the Case for an International Currency Transactions Tax," Challenge, (May/June, 2001a), 70-89.

"Escaping the "Policy Credibility" Trap: Reshaping the Debate Over the International Financial Architecture," Problemas del Desarrollo, 32 (Julio/Septiembre 2001b), 111-24.

, "Speculation and Tobin Taxes: Why Sand in the Wheels can Increase Economic Efficiency," Journal of Economics, 69 (1999), 113-126.

SARGENT, T.J., Macroeconomic Theory, New York: Academic Press, 1979.

TIEBOUT, C.M., “A Pure Theory of Local Public Expenditure,” Journal of Political Economy, 64 (October 1956), 416-24.

TOBIN, J., “Keynesian Models of Recession and Depression,” American Economic Review, 65 (1975), 195-202.

, Asset Accumulation and Economic Activity, Chicago: Chicago University Press, 1980. 